\title{
Brachial Plexus Cords: a Morphological Study
}

\author{
Ijoni Costabeber ${ }^{1}$, Gustavo Moura de Almeida ${ }^{2}$, Mônica Becker ${ }^{3}$, Aron Ferreira da Silveira ${ }^{4}$, \\ Dorival Terra Martini ${ }^{5}$
}

Summary: Costabeber I, De Almeida GM, Becker M, Silveira AF, Martini DT - Brachial Plexus Cords: a Morphological Study.

Background and objectives: The brachial plexus represents an important network of nerves, commonly approached in nerve blocks prior to surgical procedures. Therefore, the knowledge of its anatomy is indispensable so those procedures can be carried out accordingly. The objective of the present study was to analyze the morphology of brachial plexus cords with special emphasis to its topographic relationships.

Methods: This study was undertaken by dissecting the cervical, axillary, and brachial regions of a human cadaver fixed in $10 \%$ phormol, from the Human Anatomy Laboratory of the Morphology Department of Universidade Federal de Santa Maria. Access to the cords was obtained by pushing back the pectoralis minor and pectoralis major muscles, clavicular section, and extraction of part of the subclavius muscle.

Results: Cords originated from the anterior and posterior divisions of the trunks (upper, middle, and lower) of the brachial plexus. The lateral fascicle originated from the anterior divisions of the upper and middle trunks; the posterior, from the posterior divisions of the trunks; and the middle fascicle consisted from the continuation of the anterior division of the lower trunk. The cords showed relationships with the axillary artery, and they were located posteriorly to the pectoralis minor muscle, close to its insertion on the coracoid process.

Conclusions: The results were in concordance with the anatomical descriptions of classical authors. This study allowed the analysis of the morphology of the brachial plexus cords, demonstrating its main topographic relationships.

Keywords: ANATOMY: brachial plexus.

[Rev Bras Anestesiol 2010;60(6): 614-619] OElsevier Editora Ltda.

\section{INTRODUCTION}

The brachial plexus represents an important network of nerve fibers that innervate the upper limbs ${ }^{1}$. It is a peripheral structure widely approached in clinical and surgical procedures. Thus, the plexus is evaluated for the diagnosis of orthopedic lesions, such as neurovascular compression of the subclavian artery and the brachial plexus caused by the thoracic outlet syndrome ${ }^{2}$. Besides, it is the target of anesthetic blockades for surgeries of the proximal upper limbs, such as interscalene and intersternocleidomastoid anesthesia ${ }^{3}$.

Due to those implications, studies to increase and define the morphologic knowledge of segments of the brachial plexus are necessary to work as anatomical substrate for safe interventions on this topography. The objective of the present study was to analyze the morphology of brachial plexus cords, with special attention to its topographic relationships.

Received from the Universidade Federal de Santa Maria, UFSC, RS, Brasil.

1. Pharmacist, Professor at UFSC

2. Medical Student at UFSC

3. Physician, Professor at UFSC

4. Veterinarian, Professor at UFSC

5. Dentist, Professor at UFSC

Submitted on June 23, 2010

Approved on June 25, 2010.

Correspondence to:

Profa. Dra. Ijoni Costabeber

Setor de Anatomia Humana, Departamento de Morfologia, Centro de Ciências da Saúde,

Universidade Federal de Santa Maria - UFSM, Av. Roraima, no 1000

97105-900 - Santa Maria, RS

E-mail: ijonicostabeber@gmail.com

\section{METHODS}

Analysis of the brachial plexus cords was undertaken after dissecting the cervical, axillary, and brachial regions of a human female cadaver, approximately 60 years old, fixed in $10 \%$ formaldehyde, from the Human Anatomy Laboratory of the Morphology Department, Universidade Federal Santa Maria. Methodologies currently described were adapted for the dissection of the structures ${ }^{4,5}$. Thus, the access to the cords was obtained after dislocating the pectoralis major and minor muscles (and corresponding fascias) on the direction of their insertions and through section of the clavicle and extraction of a segment of the subclavius muscle. We tried to preserve the vasculature to demonstrate the vasculonervous relationship. A pair of curved anatomical scissors was used to obtain cleavage planes, scalpels number 24 for skin incisions and section of muscle fibers, and 11 for the dissection of the cords. Images were captured with a digital camera (Canon Power Shot SD450) and later catalogued. This study represents the partial results of a teaching project whose objective is the anatomical investigation of the brachial plexus to aggregate theoretical-practical material for the study of this anatomic segment, approved by the Ethics on Research Committee of the Universidade Federal de Santa Maria, according to the Presentation Certificate for Ethical Appreciation \#0207.0.243.000-08.

\section{RESULTS}

The brachial plexus was shown to be an extensive nervous network that initiated in the cervical spine and extended until the 
axilla. It was identified that throughout this path this network is organized in five distinct portions: roots, trunks, divisions, cords, and terminal branches (peripheral nerves) (Figure 1). Thus, the original roots of the plexus correspond to the anterior branches of the lower four cervical nerves (C5-C8) and the first thoracic (T1). After leaving the intervertebral foramen the anterior branch of $\mathrm{C} 5$ joins the anterior branch of $\mathrm{C} 6$ forming the upper trunk. The anterior branch of $\mathrm{C} 7$ constitutes isolatedly the middle trunk. The anterior branch of $\mathrm{C} 8$ joins that of $\mathrm{T} 1$ to form the lower trunk. Throughout this path, the brachial plexus is located between the anterior and middle scalene muscles. After passing the lateral margin of the anterior scalene muscle the trunks become more superficial, and are crossed anteriorly by the omohyoid muscle. From this point on, the nerve fibers get closer to each other, crossing the posterior aspect of the clavicle and subclavius muscle (cervicoaxillary channel), where each trunk forms two divisions, one anterior and one posterior.

In its lower course, posteriorly to the pectoralis major muscle and close to the upper border of the pectoralis minor muscle, the trunk divisions form the cords of the brachial plexus (Figure 2). The three posterior divisions join to form the posterior cord that is formed by the fibers from the three trunks (upper, middle, and lower). The anterior divisions of the upper and middle trunks join to form the lateral cord. The anterior division of the lower trunk remains independent and forms the middle cord.

The cords are located posteriorly to the pectoralis minor muscle, close to its insertion in the coracoid process of the scapula (Figure 2). They have a significant topographic posterior, lateral, and medial relationship with the axillary artery, determining the anatomical designation of the cords (Figure 3). The axillary vein is located anterior to the artery, being similarly covered by the pectoralis major and minor and subclavius muscles. The brachial plexus and axillary vessels are surrounded by a fascial sheath that originates from the fascias of the anterior and middle scalene muscles and extends up to the proximal third of the arm. Peripheral nerves that innervate the muscles of the upper limb and the thoracic wall are the products of the formation of the plexus.

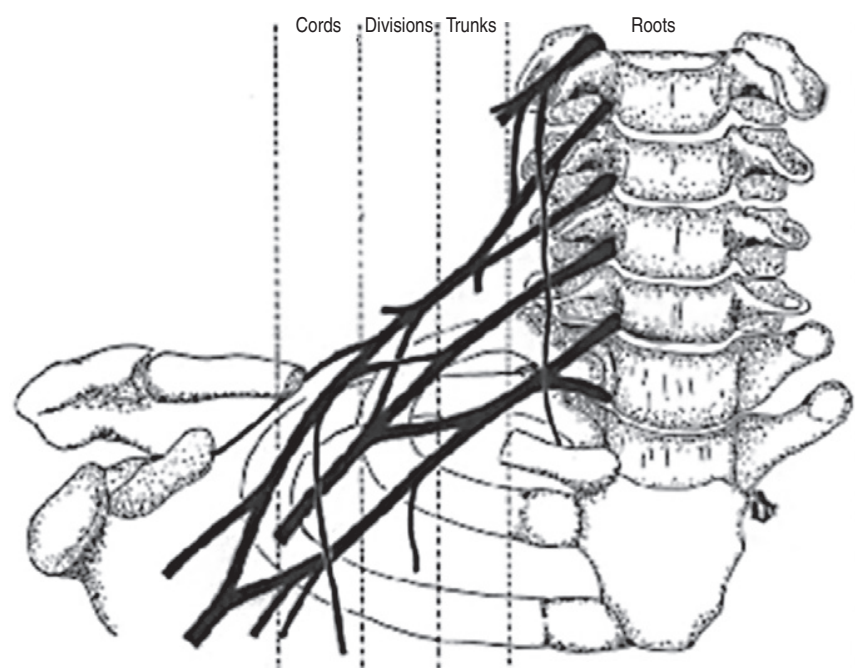

Figure 1. Schematic Diagram Showing the Origins and Organization of the Brachial Plexus.

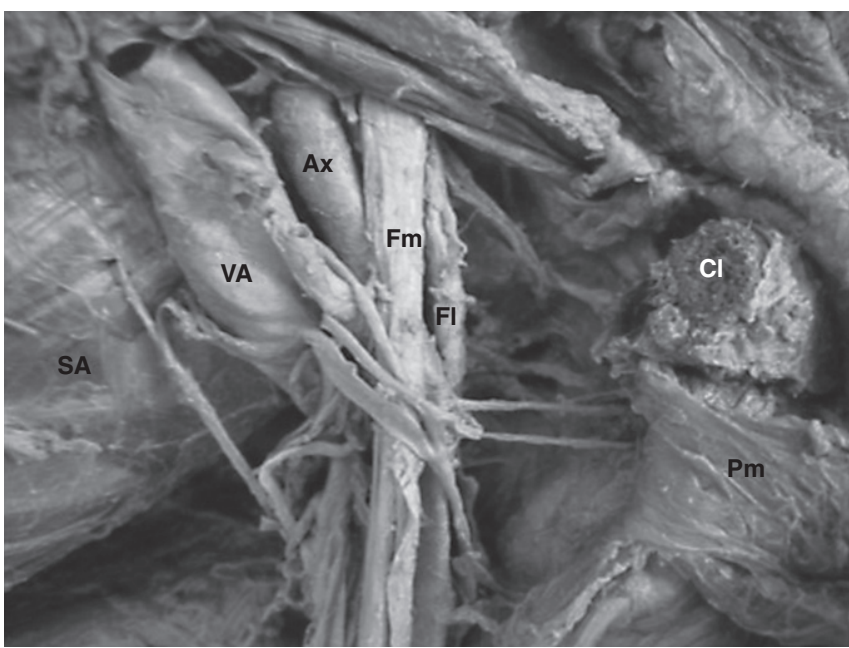

The lateral $(\mathrm{Fl})$ and middle $(\mathrm{Fm})$ cords are related to the axillary artery $(\mathrm{Ax})$ and they are located posteriorly to the pectoralis minor muscle (Pm), close to its insertion in the coracoid process. Clavicle ( $\mathrm{Cl}$, sectioned); anterior serratus muscle (SA); axillary vein (VA)

Figure 2. Topographical Relationships of the Brachial Plexus Cords.

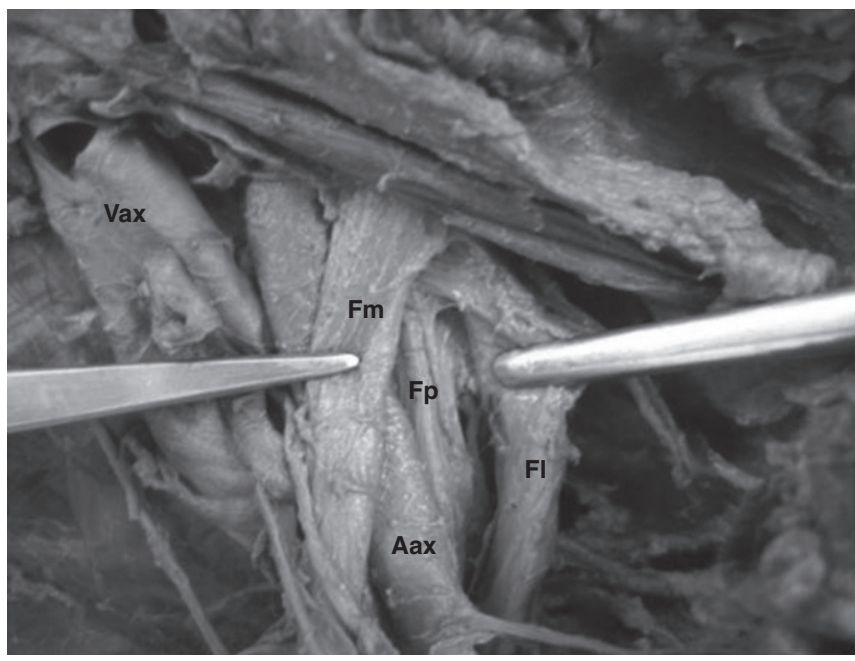

The subtle dislocation of the lateral $(\mathrm{Fl})$ and middle $(\mathrm{Fm})$ cords provides the view of the posterior Cord (Fp). Note the relationship of the cords with the axillary artery (Aax) and vein (Vax).

Figure 3. Brachial Plexus Cords.

\section{DISCUSSION}

The present study demonstrated that brachial plexus cords originate from the anterior and posterior divisions of the trunks (upper, middle, and lower), in agreement with classical anatomical descriptions 6,7 .

Anatomical investigations are elaborated to elucidate the topographical relationships of brachial plexus cords. Thus, the cords represent a reorganization of the trunks when they cross the axilla, inferior to the clavicle and superior to the first rib ${ }^{8}$. This area, known as infraclavicular or plexus expansion sector, is delimited below the skin by the pectoralis major and minor muscles, posteriorly to the vasculo nervous bundle by 
the anterior serratus muscle, and posteriorly by the pleura ${ }^{9}$. The findings of the present study confirmed those observations.

Additionally, the cords have relationships (posteriorly, laterally, and medially) with the axillary artery ${ }^{1}$. Complementarily, one study with volunteers using MRI images showed that the cords are located $2.5 \mathrm{~cm}$ from the center of the axillary artery ${ }^{9}$. However, those results are discordant with another description ${ }^{10}$ that considered this same relationship with the subclavian artery. Those differences could be explained by the fact that it was not taken into consideration the fact that the subclavian artery is called axillary artery when it crosses the external surface of the first rib ${ }^{11}$.

In the present study, it was possible to demonstrate the topographical situation of the cords posteriorly to the pectoralis minor muscle, close to its insertion in the coracoid process ${ }^{11}$. This proximity could be due to the position of abduction of the upper limb used to gain access to the cords, allowing the movement of those nervous structures towards the coracoid process. This analysis can be rectified by the fact that the axillary artery and vein, as well as the brachial plexus cords, are surrounded by adipose tissue, which obeys the movements of the upper limb in relation to the thorax ${ }^{7}$. This finding could justify the compression of the cords between the tendon of the pectoralis minor muscle and the coracoid process in situations that promote prolonged hyperabduction of the upper limb 1,2 .

The present study, therefore, allowed the analysis of the morphology of the brachial plexus cords demonstrating its main topographical relationships, an indispensable knowledge to the judicious use of clinical-surgical techniques on this nervous network.

\section{ACKNOWLEDGEMENTS}

Gustavo Moura de Almeida acknowledges the Conselho Nacional de Desenvolvimento Científico e Tecnológico (CNPq) for the grant received through the Programa Institucional de Bolsas de Iniciação Científica, and to Professor ljoni Costabeber, for the Bolsa Produtividade em Pesquisa. The authors would like to extend their special thanks to the Veterinary Medicine student, Émerson Salvagni, for the drawing of Figure 1. 


\section{REFERÊNCIAS / REFERENCES}

01. Moore K, Dalley A - Anatomia Orientada para a Clínica. 5를 Ed, Rio de Janeiro, Guanabara Koogan, 2007:1101.

02. Evans RC - Exame Físico Ortopédico Ilustrado. 2 ${ }^{\mathrm{a}}$ Ed, Barueri, Manole, 2003;1035.

03. Dewees JL, Schultz CT, Wilkerson FK et al. - Comparison of two approaches to brachial plexus anesthesia for proximal upper extremity surgery: interscalene and intersternocleidomastoid. AANA J, 2006;74:201-206.

04. Mizeres N, Gardner E. - Métodos de Dissecção. $1^{a}$ Ed, Rio de Janeiro, Guanabara Koogan, 1963:96

05. Weber JC - Manual de dissecção humana de Shearer. $8^{a}$ Ed, Barueri, Manole, 2001; 375.

06. Testut L, Latarjet A - Tratado de Anatomía Humana. 9aㅡ Ed, Barcelona, Salvat, 1978;1237.

07. Latarjet M, Liard R - Anatomia Humana. $2^{\mathrm{a}}$ Ed, São Paulo, Panamericana, 1993:958.

08. Aumüller G, Aust G, Doll A et al. - Anatomia. $1{ }^{\text {a }} \mathrm{Ed}$, Rio de Janeiro, Guanabara Koogan, 2009;1317.

09. Orebaugh SL, Williams BA - Brachial plexus anatomy: normal and variant. Scient World J, 2009;9:300-312.

10. Vieira JL - Bloqueio do plexo braquial. Rev Bras Anestesiol, 1995; 45 (n. especial): 106-115 - Atlas de Técnicas de Bloqueios Regionais.

11. Goffi FS - Técnica Cirúrgica: Bases Anatômicas, Fisiopatológicas e Técnicas da Cirurgia. 4aㅡ Ed, São Paulo, Atheneu, 2004;822.

Resumen: Costabeber I, De Almeida GM, Becker M, Silveira AF, Martini DT - Fascículos del Plexo Braquial: un Estudio Morfológico.

Justificativa y objetivos: El plexo braquial corresponde a una importante red de nervios que generalmente se aborda en los bloqueos nerviosos previos a procedimientos quirúrgicos, de modo que su conocimiento anatómico es una condición indispensable para que esos procedimientos se desarrollen perfectamente. Así, el presente estudio objetiva analizar la morfología de los fascículos del plexo braquial, con un especial interés en sus relaciones topográficas.

Método: El trabajo fue realizado por medio de una disección de las regiones cervical, axilar y braquial de un cadáver humano en formol al $10 \%$, proveniente del Laboratorio de Anatomía Humana del Departamento de Morfología de la Universidade Federal de Santa Maria. Se obtuvo el acceso a los fascículos mediante la resección de los músculos pectorales mayor y menor, la sección clavicular y la extracción de parte del músculo subclavio.

Resultados: Los fascículos se originaron en las divisiones anteriores y posteriores de los troncos (superior, medio e inferior), del plexo braquial. El fascículo lateral se originó en las divisiones anteriores de los troncos superior y medio, y en el posterior de las divisiones posteriores de los troncos, y el fascículo medial consistía en la continuación de la división anterior del tronco inferior. Los fascículos se relacionaban con la arteria axilar y estaban ubicados posteriormente al músculo pectoral menor, próximo a su inserción en el proceso coracoides.

Conclusiones: Los resultados se mostraron a tono con las descripciones anatómicas de los autores clásicos. Este estudio permitió analizar la morfología de los fascículos del plexo braquial, evidenciando sus principales relaciones topográficas. 